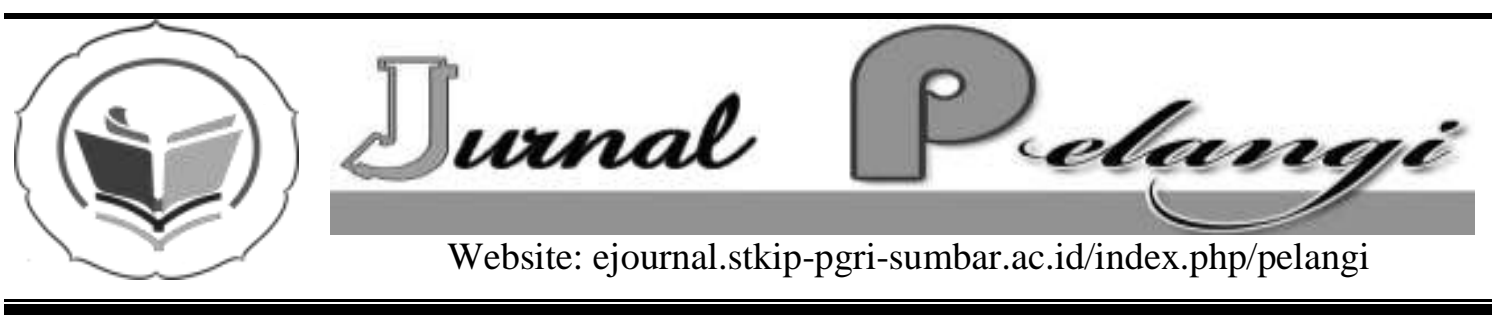

\title{
ANALISIS KRITIS TENTANG POLEMIK IMAM ALGHAZALIDAN IBNU RUSYD TENTANG KEBANGKITAN JASMANI
}

\section{Adi Yalmon}

\section{INFO ARTIKEL}

Diterima :

$01 / 04 / 2011$

Disetujui:

$30 / 05 / 2011$

Keywords:

\begin{abstract}
Sritical analysis of the polemic of imam ghazali and Ibnu rusyd about the physical punishment on the judgement day eventhough. Iman Al-ghazali and Ibnu rusydhave different ideals and arguments about the punishment all the judgement day, both of them have a great contribution to the progress of Islamic thought. Rationally, it can be said that Ibnu rusdy has encounter Al-ghazaly criticsm, but from the affection of Islamic world, Al-ghazaly more powerful that Ibnu rusdy. The latest philosopher is well know and he also called "hujjat al islam".
\end{abstract}




\section{PENDAHULUAN}

Dalam dunia filsfat islam dikenal adanya polemik antaraAl-Ghazali dan Ibnu Rusyd, walaupun keduanya tidak hidup dalam masa yang bersamaan. AlGhazali hidup dari tahun 1059 M sampai tahun $1111 \mathrm{M}$, sedangkan Ibnu Rusyd hidup dari tahun 1126 M sampai tahun 1198 M. Jika dilihat secara historis, polemic itu timbul karena AlGhazali dengan penuh kesungguhan mengkritik habis-habisan kaum filosof. Hal ini terlihat dari karyanya yang berjudul "Tahafatul al-Falasifah" yang di dalamnya ia mengungkapkan tentang kekeliruan para filosof dalam berbagai masalah. Bahkan ia tidak segan-segan mengklaim bahwa kaum filosof adalah kafir karena menurut penilaiannnya beberapa hasil pemikiran filosof tersebut bertentangan dengan syara khususnya dalam tiga masalah pokok yaitu:

1. Masalah qadimnya alam

2. Masalah pengetahuan Tuhan yang tidak sampai pada masalah-masalah yang terperinci (juziyat)

3. Masalah kebangkitan jasmani

Kritikan Al-Ghazali sebagimana diketahui dalam sejarah, sempat mematikan langkah filsafat sementara waktusehingga sampai bangkitnya seorang filosof besar Islam di Andalusia yang bernama Ibnu Rusyd. Ibnu Rusyd inilah yang berani tampil mewakili filosof dalam memberikan jawabanjawaban terhadap segala kritikan dan tuduhan yang dilontarkan oleh AlGhazali. Di dalam bukunya "Tahafut alTahafut", Ibnu Rusyd mencoba mengungkapkan kerancuan atau kekacauan cara berpikir Al-Ghazali dalam memahami pemikiran filosof. Tetapi sebagaimana yang diketahui bahwa Ibnu Rusyd lahir setelah 15 tahun wafatnya Al-Ghazali, tentu saja jawaban-jawaban Ibnu Rusyd tidak mendapat tanggapan baik dari AlGhazali. Dengan demikian seolah-olah Ibnu Rusyd keluar sebagai pemenang dalam polemik.

Tanpa ada tujuan penulis untuk mengatakan siapa yang menang atau kalah daripolemikantara Al-Ghazali dan Ibnu Rusyd, yang pasti polemik itu sendiri telah meninggalkan argumentargumen yang merupakan warisan pemikiran Islam yang sangat tinggi nilainya dan memerlukan kajian ulang secara obyektif. Untuk itulah penulis mencoba mengangkat salah satu dari tiga masalah pokok yang telah disebutkan di atas yaitu masalah kebangkitan jasmani dan mencoba melakukan suatu analisa kritis terhadap polemik keduanya antara Al-Ghazali dan Ibnu Rusyd. Masalah ini erat pula kaitannya dengan masalah kenikmatan yang ada di Syorga dan kesengsaraan di Neraka yang bersifat material. Permasalahannya adalah bagaimana pemikiran sebenarnya Al-Ghazali dan Ibnu Rusyd tentang kebangkitan jasmani serta tentang Syorga dan Neraka.

\section{PEMBAHASAN MASALAH}

A. Riwayat Ringkas Al-Ghazali dan Ibnu Rusyd

Al-Ghazali nama lengkapnya Abu Hamid Muhammad Al-Ghazali, lahir diTus pada tahun 1059 M sampai tahun 1111 M.Ia belajar fikih kepada Muhammad bin Muhammad Razkani al-Tusi dan juga kepada Imam AlJuwaini seorang Guru besar Madrasah Nizhamiyah ketika itu. Al-Ghazali dapat digolongkan sebagai filosof Islam 
terkemuka meskipun ia sendiri terangterangan mengecam parafilosof. AlGhazali digolongkan dalam jajaran filosof Islam karena pemikirannya yang bercorak filsafat dan berpikir secara logika (mantiq). Selain itu, ia juga memiliki corak pemikiran kalam sehingga dalam kritikannya terhadap filosof, ia sering menempatkan dirinya sebagai ulama mutakallim. Lebih dari itu ia juga memasuki dunia tasawwuf yang mana di dalamnya ia menemukan kepuasan bathin yang sebenarnya. Dengan demikian Al-Ghazali merupakan satu-satunya pemikir Islam yang terjun dalam tiga lapangan yaitu; filsafat, ilmu kalam, dan tasawuf.

Diantara karyanya yang terkenal selain dari "Tahafut al-Falasifah"ialah "Maqshid al-Falasifah, Mikyar al-Ilm dan Al-Munqizh min al-Dalal". Dalam bidang fikih dan akhlak, buku-bukunya yang paling berpengaruh adalah "Ihya Ulumudin", buku ini menjadi hujjah secara umum di kalangan ummat Islam khususnya yang bermazhab Sunni dan Syafii sehingga Al-Ghazali dikenalsebagai Hujjat al-Islam (Holt, 1997:600). Walaupun Al-Ghazali mempergunakan mantiq, keorisinalan pemikirannya tetap menampakkan identitas Islam yang didukung oleh dalil-dalil Al-Quran dan Hadits. Tetapi cara berpikirnyapun tidak luput dari hahal yang antagonistis atau secara tidak disadari mengandung pertentangan dengan syara'. Di lain pihak filosof Islam ketika itu setelah mendapat serangan dari Al-Ghazali, sedikit banyaknyamerasa terdorong untuk memperdalam pemikiran filsafatnya. Menurut Harun Nasution (1985:8) pendapat yang mengatakan bahwa filsafat Islam menjadi mundur adalah akibat serangan dari Al-Ghazali tidak dapat diperangi atau dibantah. Sebabternyata filsafat Islam tetap berkembang di Andalusia dan disana pula lahir Ibnu Rusyd seorang filosof Islam yang kelak namanya menjadi cemerlang karena reaksinya yang sangat tajam dalam mejawab kritikan dan tuduhan yangdilontarkan oleh AlGhazali terhadap para filosof.

Ibnu Rusyd nama lengkapnya adalah 'Abdul al-Walid Ibnu Ahmad Ibnu Muhammad Ibnu Rusyd, lahir di Cordova pada tahun 1126 M. Selain sebgai filosof, ia juga pernah menjadi hakim di beberapa kota di negeri itu dan juga pernah menjadi dokter di Istana. Dengan demikian pengaruhnya dikalangan keluarga Istana cukup besar. Tetapi kemudian keadaan berbalik, ketika pengaruh ulama fikih mendominasi penguasa maka Ibnu Rusyd dibuang oleh Sultan Abu Yusuf ke Lecena dekatCardova. Setelah itu ia pendah ke Maroco dan wafat di sana pada tahun 1198 M. Ibnu Rusyd dituduh membawa ajaran-ajaran yang menyeleweng dari ajaran-ajaran yang menyeleweng dari ajaran Islam, bahkan sampai buku-bukunyapundibuang dan dibakar bersama buku-buku filsafat lainnya. Penyebabnya adalah karena sikap keras ulama fikih dan penguasa Andalusia ketika itulah yang memulai gerakan anti filsafat, yang pada gilirannya mengendor semangat berfilsafat dikalangan dunia Islam secara umum. Buku-buku Ibnu Rusyd yang terkenal, selain Yahafatul alTahafut, dalam bidang fikih ia menulis buku Bidayat al-Mujtahid. Setelah itu ia juga banyak menulis komnetar tentang filsafat Aristoteles sehingga ia pun 
dikenal di Barat sebagai The commentator(Abas Mahmud: 30).

Berdasarkan uraian tersebut di atas maka dapat dipahami bahwa Al-Ghazali menampakkan satu sisi identitas Islam yaitu bertumpu pada teks-teks Al-Quran dan Hadis. Sedangkan di sisi lainnya dapat diperhatikan bahwa Ibnu Rusyd memperlihatkan bahwa Islam dapat mengakomodasi pemikiranfilsafat tanpa merusak keimanan. Dalam jawabannya terhadap kritik Al-Ghazali khususnya dalam masalah kebangkitan jasmani, ia menempuh jalan penakwilan ayat-ayat Al- Quran dan Hadis guna menyesuaikannya dengan filsafat. Bagi Ibnu Rusyd, nash-nash itu tidak seluruhnya harus diartikan menurut teks tetapi juga ada yang harus diartikan dengan jalan ta'wil (Muhammad Yusuf Musa, : 97-98).Dengan kata lain, menurut Ibnu Rusyd nash-nash itu mempunyai arti lahir dan arti batin.

$\begin{array}{lcr}\text { B.Kritikan } & \text { Al-Ghazali } & \text { Terhadap } \\ \text { Pandangan } & \text { Filosof } & \text { Tentang } \\ \text { Kebangkitan } & \text { Jasmani dan } & \text { Kehidupan } \\ \text { Ukhrawi } & & \end{array}$

\section{Kebangkitan Jasmani}

Pada umunya filosof berpendapat bahwa yang abadi itu hanyalah roh, baik sebagai jiwa individu maupun sebagai jiwa universal sedangkan jasmani akan hancur dan tidak kekal (De Boer, 1967:163). Oleh karena itu menurut filosof, yang akan dibangkitkan nanti di akhirat adalah roh tanpa jasmani. Sebelum melemparkan kritikannya terhadap pandangan para filosof, AlGhazali mengemukkan tiga kemungkinan bagi kebangkitan jasmani yang mana semuanya ditolak oleh para filosof. Ketiga kemungkinan tersebut diungkapkan oleh Al-Ghazali sebagai berkut:

a. Jasmani yang sudah menjadi tanah itu dibangkitkan di akhirat dengan kehidupan yang baru, bukan lanjutan kehidupannya di dunia. Ini terjadi kalau dikatakanbahwa hakekat adalah jasmani, sedang hidupnya hanya sifat

b. Jiwa manusia tetap ada sesudah matinya badan, kemudiandikembalikan kepada jasmaninya yang pertama dengan anggota-anggotanya itu sendiri seperti semula.

c. Jiwa akan dibangkitkan kembali dengan menempati suatu badan, baik badan semula ataukah badan baru yang lain. Badan atau jasmani tidak menjadi soal karena hakekat manusia bukan badannya atau jasmaninya melainkan jiwanya.

Menurut Al-Ghazali ada tigaalasan para filosof menentangpendapatnya tentang kebangkitan jasmani di akhirat yaitu:

a. Filosof menolak kemungkinan pertama karena hal semacam itu bukanlah kebangkitan. Yang dimaksud kebangkitan ialah kembalinya sesuatu yang pernah hidup kemudian dihidupkan kembali sesudah matinya sebagai lanjutan kehidupnnya yang pertama. Misalnya jika dikatakan bahwa si Badu kembali ke negerinya, maksudnya bahwa ia pernah berada di negerinya dan kembali lagi setelah ia pernah tidak berada di sana; kembalinya itu adalah lanjutan keberadaannya yang pertama

b. Kemungkinan kedua juga mustahil terjadi karena badan manusia telah hancur lebur bersama tanah sesudah mati. Sebahagian diserap oleh bakteri-bakteri, tumbuh-tumbuhan dan berpindah ke tubuh hewan pemakan tanaman, dan tidak mustahil juga beralih ke dalam tubuh manusia yang memakan tumbuh-tumbuhan dan hewan itu. Akibatnya ialah terjadinya 
peralihan satu badan terjadi milik banyak orang. Hal ini menimbulkan kesulitan untuk membangkitkan satu badan untuk banyak jiwa. Lagi pula, diantara manusia ada yang jasmaninya cacat seperti buta, tuli dan sebagainya. Bagaimana ia akan merasakan sorga apabila jasmaninya yang demikian itu akan dibangkitkan.

c. Kemungkinan ketiga juga ditolak oleh filosof, alasannya menurut AlGhazali karena berdasarkan dua alasanyaitu; pertama, materi yang menerima kejadian dan kemusnahan itu jumlahnya terbatas, sedang jiwa yang terpisah dari badan tidak terbatas jumlahnya sehingga jumlah materi tidak mungkin mencukupi jiwa, kedua, tanah sebagai "tanah" tidak dapat menerima kehadiran jiwa kecuali jika unsur-unsurnya bercampuran dan berproses sedemikian rupa. Sebagaimana percampuran dalam proses biologis dengan susunan anggota-anggotanya yang lengkap terdiri dari daging dan tulang, masih terdapat pula kesulitan untuk mngembalikan jiwa kepadanya. Kesulitan itu disebabkan karena badan yang terjadi dari proses biologis itu dapat tumbuhi jiwa dari unsur-unsur biologisnya sendiri sebelum jiwa lain ditempatkan padanya sehingga pada badan yang satu akan bertemu dua jiwa. Penempatan jiwa pada badan yang bukan miliknya dinamai juga sebagai transmigrasi (tanasukh) jiwa, suatu hal yang mustahil terjadi.

Dalam menanggapi tiga kemungkinan bagi pembangkitan jasmani sebagaimana disebutkan diatas, AlGhazali mengkhususkan perhatiannya pada kemungkinan ketiga. Boleh jadi pada kemungkinan ketiga itulah AlGhazali dapat mengajukan argumenargumen filosof menyangkut dua kemungkinan tersebut, atau setidaktidaknya ia tidak dapat membantah argumen-argumen mereka. Maka tinggallah kemungkinan ketiga, yang menurut Al-Ghazali dapat saja terjadi di hari kebangkitan nanti. Untuk kemungkinan ketiga ini setidaktidaknya Al-Ghazali mngemukakan tiga macam dalil atau alasan sebagaimana dapat dilihat dalam karyanya Tahaful al-Falasifah. Dalil itu adalah dalil kekekalan jiwa, dalil kekuasaan mutlak Tuhan dan dalil perubahan hukum alam. Untuk lebih jelasnya satu persatu dalil ini akan dianalisa sebagai berikut:

a. Dalil pertama, kekekalan jiwa dan perlunya jasmani bagi jiwa. Seiring dengan pendapat filosof, AlGhazali jugamengakui kekekalan jiwa dengan mengutip nash dari firman Allah SWT surat Ali Imran ayat 169. Di samping itu AlGhazali juga menerangkan bahwa terdapat riwayat-riwayat yang menyatakan bahwa arwah orang yang sudah mati itu merasakan kebaikan-kebaikan dan sedekah yang dilakukan di dunia, menerima pernyataan dari Malaikat Mungkar dan Nangkir, dan mersakan azab kubur, yang semuanya itu menunjukkan kekalnya jiwa. Menurut Al-Ghazali dalil-dalil syara' tersebut menunjukkan bahwa kekekalan jiwa dan sekaligus menunjukkan adanya pembangkitan jasmani. Hal ini menurut AlGhazali mungkin saja terjadi karena hakekat manusia adalah jiawanya bukan jasmani. Bukankah jasmani itu sendiri berubah-ubah dan berganti-ganti unsur-unsurnya seperti berkembang dari kecil menjadi besar, kadang-kadang gemukatau kurus, dan bergantiganti gizi makanannya, padahal manusianya tetap itu juga yaitu jiwa. Al-Ghazalimeyakini bahaAlllah SWT sangat mudah 
mengadakan jasmani untuk kepentingan jiwa di akhirat. Pentingnyajasmani bagi jiwa adalah karena jiwa tidak dapat merasakan kenikmatan dan kesengsaraan jasmaninya di akhirat dengan hilangnya raga atau jasmani yang pertama. Untuk itu perlu disediakan untuknya jasmani, yang menyerupai jasmani semula dengan jalan membangkitkan jasmani yang baru. Menurut Al-Ghazali, demikian itulah makna kebangkitan yang sebenarnya (fa kabazalik' awda muhaqqaqa) (1972:199).Padadalil pertama ini, kritik Al-Ghazali tidak mengenai sasaran bahkan menjadi bomerang bagi dirinya sendiri. Penetapannya tentang kekekalan jiwa, memang tidak menjadi masalah karena hal itu di samping didukung oleh berbagai dalil syara' juga dibenarkan oleh para filosof. Yang menjadi masalah ialah pembangkitan jasmani, yang mana menurut Al-Ghazali tidak mutlak dari materi badannya semula. Di sinilah Al-Ghazali terseret kepada kemungkinan-kemungkinan yang tidak didukung oleh syara', mestinya ia memilih kemungkinan yang kedua yang jelas-jelas didukung oleh dalil-dalil syara' yakni pembangkitan jasmnai yang disusun dari materi badannya semula, bukan dari materi lain. Dalam hal ini banyak ayat AlQuran yang menerangkan secara lahiriyah demikian diantaranya surat Al-Shaffat ayat 16-18 dan surat Yasin ayat 78-79. Seperti diketahui, Al-Ghazali menetapkan perlunya badan bagi jiwa adalah dengan alsan bahwa jiwa sangat membutuhkan alat berupa badan untuk dapat merasakan kenikmatan dan kesengsaraan yang bersifat jasmaniyah di akhirat. Jika demikian alasan Al-Ghazali maka seharusnya alat yang terbaik untuk dibangkitkan bagi jiwa adalah badannya sendiri yangpernah dipakai unrtuk beramal di dunia, karena badan itulah yang lebih berhak merasakan hasil amal perbuatannya (De Boer, 1967:74). Oleh karena Al-Ghazali tidak memastikan pembangkitan jasmani secara mutlak maka secara tidak sadar ia juga turut menentangsyara'.

b. Dalil kedua, bahwa jasmaniakan dibangkitkan berdasarkan kekuasaan mutlak Tuhan. Dalil ini adalah dimaksudkan untuk membantah agumenfilosof tentang keterbatasan materi sehingga tidak cukup untuk dijadikan badan bagi jiwa yang tidak terbatas jumlahnya.Menurut Al-Ghazali, Tuhan Maha Kuasa untuk menciptakan banyak materi baru dan kemudian Dia jadikan sekian banyak badan sesuai jumlah jiwa yang membutuhkannya. Hal ini tidak dapat diingkari karena mengingkari kemungkinan terciptanya materi-materi ciptaan Tuhan dalam menciptakan (AlGhazali, 1972:225).

Sebenarnyadalil kekuasaan Tuhan untuk berbuat sekehendakNya lebih tepat digunakan AlGhazali seandainya ia berada pada pendirian bahwa yang dibangkitkan oleh Tuhan adalah materi badan semula. Dan hal ini dapat saja terjadi jika didasarkan atas kekuasaan mutlak dari Tuhan.

c. Dalil ketiga, bahwa hukum alam berubah dan tidak kekal karena itu badan yang diciptakan di akhirat tidak perlu melalui proses biologis seperti halnya di dunia. Dalil ini dimaksudkan Al-Ghazali untuk melawan argumenfilosof tentang perlunya proses biologis bagi setiap penciptaan jasad. Menurut AlGhazali, badan yang disiapkan 
untuk setiap jiwa menempuh proses penciptaan yang lain sifatnya, secara alami. Proses yang tidak secara alami ini sifatnya langsung tanpa melalui proses kausalitas. Yang dimaksud dengan penciptaan secara langsung (bighair wasithah) penciptaan badan berdasarkan keMaha Kuasaan Allah SWT semata (bi mujarrad al-Qudrat). Sedangkan yang dimaksud dengan proses penciptaan badan dengan sebab kausalitas ialah penciptaan badan dengan sebab akibat yang luar biasa, tidak seperti yang berlaku pada alam dunia fana sekarang (AlGhazali, 1972:203). Sehubungan dengan hal tersebut diatas, AlGhazali memberi contoh bahwa pada alam dunia kita sekarang juga terdapat keganjilan dan keajaiban yang sulit diterima oleh orangorang yang berpikir secara lahiriyah. Misalnya terjadinya sihir , keramat, dan mukjizat. Semuanya itu jelas-jelas terjadi dengan sebab akibat yang luar biasa. Bahkan ada suatu fakta sederhana yang kita lihatdi sekitar kitabahwaada seorang tidak pernah menyaksikan sebuah besi berani manarik besi lainnya, tentu saja ia merasa ta'jub dan menyadari keterbatasan ilmunya terhadap keajaiban kekuasaan Tuhan. Kondisi sepertiinilah yang akan dialami oleh orang-orang yang mengingkari kebangkitan jasmani, yaitu ketika dibangkitkan dari kuburnya mereka akan melihat keajaiban yang diperbuat Allah SWT atas driri mereka, lalu merka menyesal sedalam-dalamnya. Di dalam AlQuran suratFushilat ayat 21 telah dinyatakan oleh Allah tentang kondisi mereka yang seperti ituyang artinya"inikah kebangkitan yang kamu dustakan". Dalil ketiga ini memang cukup kuat untuk membantah argumen dari orang yang berpendapatbahwaperlunya proses biologis bagi setiap penciptaan jasmani. Sebab jika disepakati bahwa di alam akhirat nanti akan berlaku hukum kehidupan yang lain sifatnya niscaya ada kemungkinan di sana kehidupan jasmani tidak berlaku lagi. Di sini mengahancurkan argumen sebelumnya tentang perlunya kebangkitan jasmani.

\section{Kehidupan Ukhrawi (Konsep Syorga dan Neraka)}

Sebelum mengajukan kritikannya dalam masalah ini, Al-Ghazali lebih dahulu mengungkapkan pandangan para filosof. Bahwa menurut filosof, jiwa manusia sesudah matinya akan kekal selama -lamanya, baik ia kekal dalam kebahagiaan yang tak terungkap kenikmatannya. Kebahagiaan yang abadi itu nanti akan dirasakan oleh jiwa yang sempurna (al-Nafs al-Kamilah alZakiyah), sedangkan penderitaan yang abadi akan dialami oleh jiwa yang kotor dan tidak sempurna (al-Nafs alNaqishahal-Muthikhah)(Al-Ghazali, 1972:182). Dengan demikian kebahagiaan di akhirat tidak dapat dicapai kecuali dengan jalan menyempurnakan jiwa dan mencucikannya dengan ilmu dan amal. Menurut Al-Ghazali kebutuhan jiwa terhadapilmu adalah mutlak, karena kenikmatan akal terletak pada tercapainya obyek-obyek pikiran (alMa'quilat),sebagaimana kenikmatan nafsu terletak pada apa yang dirasakannya dan apa yang inginkannya. Tetapi pikiran itu akan dapat mencapai obyek-obyek pikirnya karena terhalang oleh badan dengan segala bentuk kesibukan, perasaan, dan keinginan nafsu. Keadaan ini tak ubahnya dengan keadaan orang sakit yang tidak dapat merasakan kelezatan makanan dengan yang dihilangkan kepadanya, tetapi setelah ia sembuh niscaya iaakan merasakan betapa 
nikmatnya makanan itu. Begitu pula halnya akal, ia kan dapat merasakan kenikmatannya setelah terbebas dari badan dan segala pengaruhnya (AlGhazali, 1972:183).Sejalan dengan itu, amal ibadah juga sangat penting bagi jiwa. Kalau kesempurnaan jiwa terletak pada ilmunya, dankesucian jiwa terletak pada amal ibadahnya. Ibadahlah yang dapat membebaskan jiwa dari keinginan-keinginan nafsu, dan dari pengaruh dunia kemudian dapat mempertinggi ketaqwaan. Ibadah itu pula yang mempererat hubungan jiwa dengan urusan ukhrawi sehingga ketika ia mati, jika akan diangkat dalam keadaan terbebas dari penjara dan dapat mencapai segala keinginannya dan itulah sorganya (AlGhazali, 1972:185). Sebaliknya apabila badan telah mati sedangkan keinginan nafsu masih melekat padajiwa karena jiwa akan merasakan siksaan atas dirinya sendiri. Siksaan itu timbul karena dua hal yaitu; Pertama, karena kinginan nafsu tersebut manghalangi untuk memperoleh kenikmatan rohaninya dalam berhubungan dengan para Malaikat dan menyaksikan keindahan Ilahiyah. Kedua,karena masih adanyajiwa terhadap kelezatan duniawi, sedangkan badan yang menjadi alat untuk memperoleh telah tidak ada (hancur). Keadaan ini persis sama dengan keadaan orang yang merindukan wanita, jabatan dan harta benda tetapi wanita kerinduannya telah dibunuh orang, jabatannya telah dicopot dan harta bendanya telah dirampas habis sampai ia mengalami penderitaan yang sulit dan tak terbayangkan. Di dunia segala harapan itu masih mungkin diperoleh tetapi di akhirat harapan yang demikian itu tidak mungkin terwujud karena badan telah musnah akibat kematian (Al-Ghazali, 1972:185).

Dari pandangan filosof di atas yang diungkapkan oleh Al-Ghazali dapat dimengerti bahwa jiwa tidak akan memperoleh puncak kenikmatannya kecuali jika ia telah berpisah dengan jasadnya.

Atau dengan kata lain dalam merasakan kenikmatan itu jiwa tidak akan memerlukan adanya jasmani. Pengertian ini sejalan dengan pandangan filosof sendiri bahwa kenikmatan material tidak ada artinya jika dibandingkan dengan kenikmatan rohaniyah. Namun demikian menurut filosof kenimktan rohaniyah hanya dapat dipahami oleh manusia jika digambarkan sedemikian rupa dengan mengambil contoh-contoh dari apa yang biasa dirasakannya dalam kehidupan duniawi. Bagi filosof, ada dua alasan yang mendasari pendapat mereka tentang keutamaan kenikmatan rohaniyah atas kenikmatan jasmaniyah yaitu:

1. Bahwa keadaan para Malaikat jauh lebih mulia dari keadaan hewan, sedangkan Malaikat itu sendiri tidak merasakan kenikmatan jasmani berupakeindahan bentuk dan kelezatan makanan. Akan tetapi Malaikat hanya semata -mata merasakan kenimkatan atas kesempurnaan dan kemuliaan yang khas baginya yaitu kemampuan memahami hal-hal yang hakekat dan sifat taqarrubnya dengan Tuhan.

2. Bahwa manusia juga demikian halnya, seringkali mengutamakan kenikmatan akliyah atas kenikmatan jasmaniyah. Seseorang akan rela meninggalkan istrinya, meninggalkan akanan lezat, bahwa tidak makan sepanjang hari ketika ia sedang berperang melawan musuhnya-musuhnya hanya karena ingin memperoleh kemenangan dan sanjungan atas kemengannya. Bahkan seorang pemberaniakan meremehkan bahaya kematian demi tercapainya keinginan. Menurut filosof kenikmatan akliyah jauh lebih mulia dari kenimmatan 
jasmaniyah yang bersfiat material (Al-Ghazali, 1972:184).

Setelah Al-Ghazali menjelaskan pandangan filosof sedemikian rupa, ia mengakui bahwa sebahagian besar dari pandangan mereka itu tidak bertentangan dengan syara'. Ia nampaknya setuju bahwa di akhirat nanti akan terdapat kenikmatan rohani yang lebih tinggi nilainya dianding dengan kenikmatan duniawi yang material. Ia juga tidak menolak pendapat filosof tentang kekekalan jiwa, namun ia menegaskan bahwa hal itu diketahui melalui syara'. Yang ditolak oleh Al-Ghazali dalam hal ini adalah tiga hal yaitu; pandangan tentang kenikmatan roahani sematamata, dan penakwilan ayat mutasyabihat tentang akhirat. Satu persatu masalah ini akan dikemukakan sebagai berikut:

1. Masalah pengetahuan akal tentang urusan akhirat.

Menurut Al-Ghazali masalah kebangkitan di akhirat meliputi kebangkitan jasmani, kenikmatan sorga dan penderitaan dalam neraka, hanya bisadiketahui melalui syara'. Al-Ghazali tersebut ada benarnya karena para filosof sendiri selalu merujuk pada teks ayat dan hadis dalam meguraikan pendapat merekatentang masalah kebangkitan. Menurut Al-Ghazali ada kemampuan akal untuk mengetahui Tuhan, namun ia menolak kemampuan akal untuk mengetahui urusan-urusan yang bersifat ukhrawi (Harun Nasution, 1983:84). Tetapi yang perlu dipertanyakanapakah para filosof benar-benar bependapat bahwa masalah akhirat dapat diketahui berdasarkan pemikiran akal. Apabila benar demikian maka pendapat mereka patut ditolak, tetapi jika tidak benar maka dengan sendirinya agumen Al-Ghazali di sini tidak mengenai sasaran dalam mengkritik filosof.

2. Masalah pandangan filosof tentang kebahagiaan rohani semata-mata.l

Al-Ghazali menolak pandangan filosof yang demikian dan ia balik bertanya "apakah yang menghalangi bergabungnya dua macam kebahagiaan rohani dan jasmnai begitupun penderitaan?" (Al-Ghazali, 1972:188).

Selanjutnya menurut Al-Ghazali alasan-alasan yang dikemukakan oleh filosof bahwa kenikmatan rohani jauh lebih tinggi nilainya dari kenikmatan jasmani sehingga kenikmatan rohani tidak perlu lagi tidak dapat diterima. Karena menurutdia penggabungan antarasifat rohani dan sifat jasmani itulah yang tersempurna itulah yang dijanjikan di dalam syara'. Dalam mengartikan nash-nash yng biasa dijadikan dasar argumentasi oleh filosof, seperti yang dikemukakan terdahulu, Al-Ghazali memahami bahwa nash-nash tersbut tidak menolak secara tegas adanya kebahagiaan material di akhirat. Nash-nash itu menurut AlGhazali mengandung pengertian bahwakita tidak mengetahui segalanya tentang kebahagiaan dan penderitaan itu (Al-Ghazali, 1972:189).Argumen Al-Ghazali tersebut sebenarnya sependapat dengan para filosof, sebab walaupun nash-nash itu tidak menolak secara tegas adanya kenikmatan jasmani di akhirat, namun Al-Ghazali tidak dapatmenjadikannya sebagaian besar untuk meyakinkan orang lain tentang adanya kenikmatan jasmani itu. Dengan katalain, nash-nash itu hanya mengandung hal-hal yang bersifat mungkin pada pemahaman masing-masing orang.

3. Penakwilan ayat-ayat mutasyabihat tentang akhirat. 
Menurut filosof, apa yang dikemukakan oleh syara' mengenai akhirat khususnya kehidupan di sorga dan neraka tidak lain dari gambaran-gambaran untuk memudahkan pemahaman manusia tentang akhirat. Dengan demikian menurut filosof nash-nash tentang akhirat itu harus ditakwilkan, sebagaimana nash-nash yang mengandung tasybih tentang soalsoal kuTuhanan. Untuk masalah ketiga ini Al-Ghazali memberikan kritikannya bahwa antara gambaranakhirat dan tasybih tentang sifat Tuhan terdapat perbedaan dalam dua hal yaitu; Pertama,bahwa nash-nash yang mengandung tasybih itu dapat ditakwilkan sesuai dengan tradisi bahasa Arab, sedangkan nash-nash tentang sifat sorga dan neraka maknanya jelas sehingga tidak perlu lagi untuk ditakwilkan lagi. Penakwilan hanya mengandung arti bahwa gambaran-gambaran itu bertentangan dengan keadaan sebenarnya dan tentu saja suatu yang tidak mungkin terjadi pada fungsi kenabian. Kedua,bahwa dalil akli menolak adanya tempat, arah, bentuk, tangan, mata dan perpindahan bagi zat Allah SWT sehingga sifat-sifat tersebut perlu ditakwilkan. Sedangkan apa yang dijanjikan Tuhan di akhirat tidak mustahil bagi kekuasaanNya karna itu wajib diterima sesuai arti lahirnya (Al-Ghazali, 1972:192). Sebenarnya kalau diperhatikan jalan pikiran filosof, penakwilan tentang soal-soal akhirat yang mereka lakukan justru brtolak darianggapan bahwa masalah tersebut tidak jelas maknanya walaupun secara lahiriyah nashnash itu memang jelas. Di samping itu juga karena gambarannya tidak masuk akal bagi filosofjika ditakwilkan. Keadaan nahs-nash sedemikian itu tidak berbeda dari keadaan nash-nash tasybih tentang Tuhan yang tidak bisa dipahami kecuali denganjalan takwil. Dengan demikian dapat dikatakan bahwa kritikan Al-Ghazali dalm hal ini juga tidak mematahan argumen dari para filosof.

\section{Jawaban Ibnu Rusyd Terhadap Kritikan Al-Ghazali \\ Di sini akan dikemukakan jawaban-} jawaban dari Ibnu Rusyd secara umum tentang gugatan Al-Ghazali terhadap pemikiran para filosof namun tidak menurut urutan permasalahan yang telah dikemukakan pada bahagian yang lalu. Namun demikian sebagaimana yang akan kita lihat bahwa jawabanjawaban Ibnu Rusyd mencakup segenap masalah yang dikritik oleh Al-Ghazali mengenai masalah kebangkitan jasmani dan kehidupan ukhrawi. Tetapi tidak dapat dipungkiri bahwa jawaban Ibunu Rusyd hanya menyentuh masalah tersebut secara sekilas atau sepintas (Van Den Berg, 1954:103). Jawaban Ibnu Rusy ini dapat diklasifikasikan dalam empat argumen pokok yaitu:

\section{Filosof Menghargai Kebangkitan Jasmani \\ Menurut Ibnu Rusyd (1968:264-} 265) masalah-masalah kebangkitan jasmani sebenarnya tidakdibahas oleh filosof terdahulu yaitu filosof Yunani, walaupun masalah ini telah menjadi pembicaraan dalam syarai'ah sekurangkurangnya seribu tahun yang lalu. Oleh sebab itu kata Ibnu Rusyd orang yang pertama-tama membicarakan tentang kebangkitan jasmani ini adalah nabinabi Bani Israil seperti terlihat di dalam kitab Zabur dan kitab-kitab lainnya yang berasal dari Bani Israil. Masalah ini juga tersebut dalam kitab Injil dan riwayat-riwayat yang berkaitan dengan diri Yesus. Pada prinsipnya kata Ibnu Rusyd,filosof juga mengakui ajaran kebangkitan jasmani itu sebagagi ajaran 
pokok agamatetapi tidak dalam pengertian lahiriyah. Bagi filosof, ajaran kebangkitan jasmani ini pada hakekatnya harus dipahami dengan jalan takwil. Namun demikian menurut Ibnu Rusyd, filosof juga mengenai pentingnyaarti secara lahiriyah bagi golongan awam dalam membimbing mereka untuk mencapai kebahagiaan. Artinya keimanan pada kebangkitan jasmani secara lahiriyah sangat penting dalam mewujudkan keutamaan akahlak, keutamaanberpikir dan keutamaan amalan kahiriyah dikalanganorangaorang awam itu (Ibnu Rusyd, 1968: 285-287).Dari uraian di atas dapat dipahami bahwa perbedaan paham antara filosof dengan yang lainnya dalam masalah kebangkitan jasmnai terletak pada cara penafsiran masingmasing. Dengan demikian filosof tidak dapat dikafirkan dalam masalaah ini karna mereka juga menerimanya sebagai ajaran pokok agama walaupun mereka menafsirkannya secara lain.

\section{Perlunya Penakwilan}

Menurut Ibnu Rusyd setiap syari'at mengandung hal-hal yang hanya dapat dipahami secara umum oleh ummat.Menurut filosof bahwa hal-hal yang umum trrsebut tidak dapat dipandang remeh tetapi harus ditakwilkannya sesuai dengan jiwa syari'at. Tetapi apabila ada diantarafilosof tersebut yang meragukan serta memberikan penafsiran yang bertentangan dengan ajaran Nabi maka wajarlah mereka disebut kafir dan mereka akanmenerima akibat dari kekafirannya (Ibnu Rusyd, 1968:355358).

Seiring denganpernyataan Ibnu Rusyd tersebut, nyatanya Al-Ghazali pun dalam memahami kebangkitan jasmani sebanarnya ia juga melakukan penakwilan. Ia berpegang sepenuhnya pada teks ayat yang menyatakan kebangkitan jasmani dengan materi badan semula melainkan ia memberi kemungkinan dibangkitkannya suatu badan yang lain dari badan semula itu. Walaupun demikian penafsiran itu masih dapat dianggap sejalan dengan jiwa syari'at. Hal ini juga tentunya berlaku pada penakwilan yang dilakukan oleh filosof. Oleh sebab itu jika kita lihat pernyataan dari Ibnu Rusyd ternyata ia juga memperkuat argumennya tentang perlunya penakwilan bagi filosof, guna memperoleh pemahaman yang sesuai dengan tingkat pemikirannya. Atau dengan tegas dapat dikatakan bahwa menurut Ibnu Rusyd jika filsafat bertentangan dengan arti teks wahyu maka teks itu harus ditakwilkan sedemkian rupa agar tidak bertentangan dengan filsafat.

3. Akhirat Sebagai
$\begin{aligned} & \text { Perkembangan Tahap } \\ & \text { Kehidupan }\end{aligned}$
Menurut Ibnu Rusyd, kehidupan akhirat adalah tingkat kehidupan yang lebih tinggi dari kehidupan di dunia dan lebih mulia dari pada kehidupan sekarang. Orang yang menolak hal ini secara terang-terangan adalah orang -orang yang menentang syara' dan keutamaan hidup. Mereka itu adalah orang zindiq yang berpandangan bahwa tujuan hidup manusia tidak lain dari kenikmatan material belaka (Ibnu Rusyd, 1968:371). Argumen Ibnu Rusyd tersebut tampaknya dimaksudkan untuk menjawab argumenAl-Ghazali tentang kebangkitan jasmani di akhirat berdasarkan dalil perubahan hukum alam.Sebagaimana kita ketahui,AlGhazali membedakan antara hukum penciptaan yang berlaku pada alam sekarang dengan hukum penciptaan yang berlaku di akhirat yang prosesnya berbeda dengan proses penciptaan di dunia. Sedangkan Ibnu Rusyd melihat hukum alam di akhirat sebagaisatu rangkaian yang masing-masing berlaku menurut tiingkat perkembangnnya dan alamakhirat sebagai tingkat 
perkembangan yang lebih tinggi. Dengan demikian dapat dipahami bahwa Ibnu Rusyd kebangkitan jasmani tdiak dapat dipahami secara material karena hal semacam itu hanya bisaterjadi parda tingkat perkembangan hukum alam yang berlaku sekarang. Sejalan dengan itu Ibnu Rusyd juga melihat bahwa kebahagiaan di akhirat adalah puncak kebahagiaan yang bersfiat rohaniyah. Di akhirat katanya kabahagiaan jasmani tidak diperlukan lagi karena kebahagiaan semacam itu hanya patut berlaku pada alam sekarang sebagai tingkat terendah dari tahap-tahap perkembangan kebahagiaan itu. Dengan demikian wajar jika Ibnu Rusyd menamakan mereka yang mempertahankan kebahagiaan jasmaniah sebagai orang-orang yang zindiq karena dianggapanya menentang jiwa syari'at.

\section{Argumentasi Al-Ghazali Memperkuat Pandangan Filosof \\ Kritikan Al-Ghazaili terhadap} filosof khususnya dalam masalah kebangkitan jasmani dianggap oleh Ibnu Rusyd sebagai memperkuat pandangan filosof itu sendiri. Dalam kaitannya itu Al-Ghazali telah menunjukkan bahwa jiwa itu kekal, tidak mati, sebagaimana yang tunjukkan oleh dalil-dalil akli dan syar'i. Al-Ghazali juga mengakui bahwa yang dibangkitkan nanti di akhirat adalah sesuatu yang menyerupai jasmani semula bukan jasmani semula itu sendiri. Hal ini disebabkan karena jasmani yang telah musnah itu tidak mungkin kembali dan yang akan kembali adalah sesuatu yang menyerupainya.

Argumen Al-Ghazali tentang perlunya pembangkitan jasmani, dengan menyatakan bahwa yang akan dibangkit itu dapat saja disusun dari materi lain ternyata menjadi bumerang bagi dirinya sendiri. Dengan demikian argumen AlGhazali tersebut telah memperkokoh pandangan filosof dari dua sisi yaitu;
Pertama, bahwa Al-Ghazali tidak sepenuhnya berpegang pada teks ayat Al-Quran yang menyebutkebangkitan materi jasmani semula, sama halnya sikap yang ditempuh oleh filosof yang memahami secara takwil tanpa terikat pada teks ayat. Kedua,bahwa dengan argumen tersebut Al-Ghazali tampaknya mengakui tidak mungkinnya materi jasmani semula untuk dibangkitkan, sejalan dengan pandangan filosof tentang mustahilnya kebangkitan jasmani. Singkatnya, memang tidak dapat disangkal bahwa argumenargumen Al-Ghazali juga mengandung kelemhan di samping juga ditemukan ada yang saling bertentangan.

\section{KESIMPULAN}

Berdasarkan uraiandananalisa terdahulu disimpulkan sebagai berikut:

1. Perbedaan pandangan antara AlGhazali dan Filosof dalam masalah kebangkitan jasmani hanyalah perbedaan penafsiran belaka. Perbedaan tersebut tidak menyangkut masalah diterima atau ditolaknya ajaran itu. Ibnu Rusyd mangakui hal itu adalah sebagai dasar ajaran agama walaupun mereka memahaminya dengan jalan takwil, sedangkan Al-Ghazali adalah bertolak dari teks ayat-ayat Al-Quran dan Hadis.

2. Perbedaan penafsiran tersebut terjadi karna kedua belah pihakAlGhazali dan Ibnu Rusyd masingmasing memiliki tempat berpijak yang berbeda, yang mana AlGhazali berpijak pada pemikiran yang lebih bercorak pada ilmu kalam. Sedangkan Ibnu Rusyd dan filosof lainnya berpijak pada pemikiran filosofis yang banyak bersifat akliyah.Dengan demikian yang terjadi keduanya adalah dialog antara ilmu kalam dan filsafat.

3. Sumbangan pemikiran kedua tokoh ini Al-Ghazali dan Ibnu Rusyd dalam membahas tentang persoalan 
aqidah tersebut mempunyai arti yang sangat besar bagi perkembangan pemikiran ummat Islam.

4. Melihat relevansinya dengan kondisi ummat hari ini maka patut kiranya dijadikan sebagai acuan pola berpikir dalam menghadapi perkembangan teknologi serta derasnya arus informasi bebas nilai akan mengakibatkan hancurnya tatanan kehidupan sosial.

\section{DAFTAR PUSTAKA}

Abbas, Sirajudin(1972). Sejarah dan Keagungan Mazhab Syafi'i. Jakarta: Pustaka Tarbiyah.

Ahmad, Jamil.(1998). Seratus Seratus Muslim Terkemuka.Jakarta: Pustaka Firdaus.

Departemen Agama RI (1998). AlQuran dan Terjemahnya. Surabaya: Mahkota.

Madjid, Nurcholis. (1995). Islam Agama Kemanusiaan. Jakarta: Yayasan Wakaf Paramidana.

Muthahari, Murthada. (1992). Keadilan Ilahi: Asas Pandangan Islam. Terjm. Agus Effendi. Bandung: Mizan.

Paramadina.(1994). Paket Studi Ilam IV: Pendekatan Tematis. Jakarta: yayasan Wakaf Paramadina.

Purwadarminta W.Js. (1988). Kamus Besar Bahasa Indonesia. Jakarta: Balai Pustaka.

Rusyd, Ibnu.Bidayah Al-Mujtahid. Beirut: Dar al-Fikr Al-Islami. 1403 H. Terjmh. t.t.San'ani, al.Subul Al-Salam, Bandung: Dahlan, t.t.
Sardar, Zainudin. (1993). Tantangan

Dunia Islam Abad 21

Menjangkau Informasi.

Bandung: Mizan.

Shihab, M. Quraiys. (1992). Membumikan Al-Quran:

Fungsi dan Peran Wahyu dalam Kehidupan Masyarakat. Bandung: Mizan.

(1996). Wawasan Al-Quran. Bandung:Mizan. 